\title{
Living Arrangement
}

National Cancer Institute

\section{Source}

National Cancer Institute. Living Arrangement. NCI Thesaurus. Code C94852.

A description of a personal residence and the relationship between the occupants that reside there. 